\title{
Changing on the Inside: Restorative Justice in Prisons: A Literature Review
}

\author{
Rebecca Wallace \\ Karen Wylie \\ Robert Gordon University, Aberdeen, Scotland ${ }^{1}$
}

\begin{abstract}
In recent years there has been increasing interest in the use of restorative justice, including its use within the prison environment. This literature review first considers some of the theory and practice of restorative approaches in general terms before turning to consider their application in the Bahamian and wider Caribbean setting, particularly Jamaica and Trinidad and Tobago. The literature review was undertaken collaboratively with the College of The Bahamas faculty involved in a profiling study of the inmates held at Her Majesty's Prison Fox Hill, Nassau. The findings of that study relating to restorative justice are referred to in the review of sources.
\end{abstract}

\section{INTRODUCTION}

It is partly through disaffection with the attitude that punitive punishment is the best or most appropriate response to criminal justice issues that interest in restorative justice has grown. Whether it is in relation to giving victims of crime a central place in the justice system, rehabilitating prisoners or reducing recidivism rates, restorative justice advocates have challenged the traditional wisdom of the conventional criminal justice system. The following represents a short literature review of restorative justice, taking into account elements of theory and practice, particularly within the prison system. It was initiated to provide the contextual background to a profiling study of the inmates at Her Majesty's
Prison, Fox Hill, Nassau, conducted by Faculty members of the College of The Bahamas in 2010 (Minnis, Symonette, Gibson \& Stevenson, 2011). This study included questions to ascertain the inmates' receptiveness to restorative justice. Initially, the literature review provides an overview of restorative approaches. It is against this background that the Bahamian and Caribbean context is then considered.

\section{The Restorative Ethos and Practice}

The conventional criminal justice system views crime as a violation of laws. This approach puts the state at the heart of the process (Boyes-Watson, 2004): it is the courts, representing the state, which will attribute guilt and decide upon what is deemed to be

\footnotetext{
${ }^{1}$ Rebecca Wallace, Professor of International Human Rights and Justice; Karen Wylie, Research Assistant; Robert Gordon University, Aberdeen, Scotland.

E-mail: r.m.m.wallace@rgu.ac.uk

Acknowledgements: The authors are grateful to Madeleine Smith, former Library and Information Studies student at Robert Gordon University, for her assistance.

APA reference: Wallace, R., \& Wylie, K. (2013). Changing on the inside: Restorative justices in prisons: a literature review. The International Journal of Bahamian Studies, 19, 57-69. https://doi.org/10.15362/ijbs.v19i1.180
} 
appropriate punishment, so that the offender allegedly "gets what he or she deserves". This effectively sidelines those most immediately affected by a crime, namely victims, and also their families and friends; offenders and their families; and communities (Sawin \& Zehr, 2007). Restorative justice is instead based on the premises that crime is a violation of, or harm to, individuals and their relationships; that this harm brings obligations to the person who is responsible for it and that he or she acknowledges this accountability; and that these obligations are addressed through discussion among all those involved - the victim, the offender and members of the affected community (Zehr, 2002).

Restorative justice has been used in aboriginal communities for many years as a peacekeeping method (Achtenberg, 2000) and since the 1970s has been used, particularly in Canada, Australia and New Zealand, with youth offenders (Liebmann, 2007). As well as aboriginal communities many faith communities, for example the Mennonites (e.g. Wilson, Huculak, \& McWhinnie, 2002; Ballor, 2008), have used restorative justice practices, as this methodology supports Western Christian New Testament beliefs of forgiveness and healing. Traditionally, the crimes dealt with through restorative justice have been relatively minor or those committed by youths, although it is now sometimes considered as an option in the treatment of more serious crimes and those committed by adults, in conjunction with the criminal justice systems of many countries. Recently, the use of restorative justice has become more popular in the prison environment (Katounas \& McElrea, 2002; Wilson et al., 2002; Saxton, 2005) and it is this use which will be discussed further here.

There are many definitions of what constitutes restorative justice (Hall, 2010), in terms of principles and practice. The definition offered by the United Nations Office on Drugs and
Crime (2006) is helpful in framing practice. It defines restorative justice, in practical terms, as:

... any process in which the victim and the offender and, where appropriate, any other individuals or community members affected by a crime participate together actively in the resolution of matters arising from the crime, generally with the help of a facilitator (p. 6).

Many practices can be encompassed by this (Hall, 2010), to the extent that many interventions which are described as "restorative" may fall short (Doolin, 2007; Daly, 2002). Restorative encounters can take several forms of which the most common examples are identified here. Victim-offender mediation is a model in which there is a meeting, led by a trained facilitator, between the person harmed and the individual responsible for the harm. The participants will have the opportunity to be accompanied by supporters: family members or friends, but in this model these people generally take a secondary role. The mediation usually opens with victims being invited to tell the story about the crime from their perspective; to express what impact it has had on their lives; and to ask the offenders any questions. Offenders are then given the opportunity to talk about what they did, why they did it, and to answer any questions asked by the victims. The desired outcome is for agreement to be reached as to how the offender will try to put right the harm. Victim-offender mediation can also be conducted more indirectly by the relevant parties communicating by letters via a mediator, or through shuttle conferencing or mediation. This latter practice involves a mediator acting as a go-between for the person harmed and the offender, to negotiate answers to questions, understanding and, where appropriate, reparation, but do not meet faceto-face (SACRO National Office, 2006). 
Restorative conferencing is a similar method, bringing together the victim and offender and their supporters, who in this scenario will have more of a participatory role. Members of the wider community will also be present and they will also be encouraged to contribute. Likewise, the conference will be led by a trained facilitator. Again the outcome sought is for the offender to accept responsibility for the harm caused and to agree on how to realise his or her obligation to restore equity or make amends.

\section{Restorative Justice in the Criminal Justice and Prison Setting}

In the criminal justice system, the adoption of restorative practices has so far tended to be concentrated in the field of youth justice or, if aimed at adult offenders, at those engaged in less serious crimes (Sherman \& Strang, 2007; Dignan, 2002). This is perhaps unsurprising given the "tough on crime" attitude that appears to have a stranglehold on the public and political discourse surrounding crime and punishment, with restorative justice sometimes caricatured as a "soft" option and deemed not punishment enough (Dhamia, Mantle \& Fox, 2009; Gromet \& Darley, 2006). The debate until recently has certainly been dominated by those on the side of retributive justice, those who posit that justice is only done when the offender pays, or is seen to suffer. If this dichotomous approach is accepted it is hard to see how restorative practices can successfully be implemented within the traditional model.

However, although adopting a restorative approach is often described as representing a paradigm shift in responding to crime (Jenkins, 2004), does this either/or mindset have to be the case? Can restorative justice be integrated into the criminal justice system and prison regime without losing its characteristic elements of respect, engagement and collaboration (Wheeldon, 2009)? This is an important question as, however much advocates of restorative justice might hope for a time when retribution is no longer the primary driving force of the criminal justice process, this is unlikely to be realised soon. As imprisonment looks set to remain the principal response to adult crime for a while yet, restorative practices will need to be used in tandem with more punitive methods, at least for the foreseeable future (Dhamia et al., 2009). So returning to whether the dichotomy between restorative and retributive justice is a false one, perhaps it is helpful to avoid confusion between particular conceptions of punishment with the concept of punishment itself. Seen this way, restorative justice is not an alternative to punishment, but an alternative form of punishment (Duff, 2003). By framing the debate in these terms then, retributive and restorative justice are not dichotomous, but can be compatible.

The relationship between restorative and retributive responses to crime and the possibility of an improved approach becomes even clearer if the question is posed as to what is expected of prisons. It is now generally accepted that there is a role beyond simply incarcerating, and that prisons should have a rehabilitative function in which those locked up are offered opportunities to reform and to tackle the root causes of their behaviour in order to successfully reintegrate into society upon release (Dhamia et al., 2009). This is essential given that the vast majority of prisoners, once released, often rejoin the very communities from which they came, and they are expected to not cause further harm to those communities (Sherman \& Strang, 2007). But even if this positive role of prisons is acknowledged it cannot yet be said to be effectively filtering through to practice and too many individuals are still leaving prison with a strengthened criminal identity (Gromet \& Darley, 2006). The old cliché of prison being an "academy of crime" is still very pertinent. Recidivism rates remain high; fragmented 
relationships with family and friends, hostility and mistrust from the wider community result in an absence of support networks making post-release life precarious; and employment and educational opportunities are likely to be limited for ex-offenders. So could restorative practices within prisons make the difference, make prison a more positive experience and better prepare offenders for release?

What then should be the goals of restorative programmes within prisons? Initially these can be divided into two sets of outcomes: those to be achieved within the prison and those to be attained outside the prison and how it relates to the community in which it is situated (Coyle, 2001; Dhamia et al., 2009).

The first category of restorative projects, namely those which could be run in prisons, includes victim-offender mediation or restorative conferencing. Through these interventions offenders would be encouraged to face up to the crimes committed; to empathise with their victims; and to consider ways in which to repair the harm they have done. Family members, friends and others from the wider community could also be encouraged to participate, generating a process in which everyone is enabled to express their feelings and needs to the offender while at the same time maintaining, even strengthening, the bonds between those on both the inside and outside, the presence of which often prove to be a deciding factor in how the prisoner copes post-release (Naser \& Visher, 2006).

On another level restorative practices could be introduced as the best way to deal with internal conflict, whether it is between inmates or between prisoners and staff (Newell, 2002). Prisons are often brutal and volatile institutions in which strict hierarchies emerge or are created and in which contravention of any explicit, or indeed unspoken, rules are dealt with harshly. In what is generally a dehumanising environment, arguably for staff as well as inmates, restorative practices, based as they are on principles of respect, participation and collaboration, could arguably engender a more positive atmosphere in which conflict and tension are no longer the default condition.

As mentioned earlier, restorative practices could also be used to promote ties between prisons and communities by encouraging volunteers and visitors to go into prisons and engage with the inmates. This type of activity is already conducted for example by prison fellowship groups, and strengthens the conception of a prison being part of a community, rather than isolated from it. It also emphasises the benefit to prisoners of retaining or forging links outside the prison's confines as a means of easing their reintegration into communities (Stern, 2002).

Ultimately then, a restorative prison would be one in which prisoners are encouraged to face up to the impact of their actions; the handling of disputes and conflict within the prison community is remodelled; and relationships are supported and developed between prisoners, staff, family members, friends and communities.

Restorative justice has been introduced to prisoners either at the start of the prison sentence (Armour, Sage, Rubin, \& Windsor, 2005; Gilligan \& Lee, 2005; Saxton, 2005), or towards the end of the custodial sentence to assist the offender in reintegrating into the community (Walker \& Greening, 2010; FochtPerlberg, 2009; O'Doherty, 2004). It has also been suggested that offenders could begin the restorative justice process while in prison and complete the process out in the community (Hurley, 2009). However according to some studies, it appears that participating in restorative justice towards the end of the sentence is more beneficial to offenders in terms of feeling supported, dealing with issues contributing to offending behaviour (e.g., 
O'Brien, 2001) and the forgiveness elements of the healing process for victims and the community (Witvliet et al., 2008).

The notion of a restorative prison as a whole entity as opposed to ad hoc restorative programmes being administered within it, is gaining popularity (Edgar \& Newell, 2006; Goulding, Hall, \& Steels, 2008; Bazemore, Zaslaw, \& Riester, 2005). This concept suggests a prison wide approach to restorative justice to which all staff, inmates and outside agencies must adhere. This includes restorative justice for prisoner-to-prisoner violence (Findlay, 2002), bullying and other complaints (Edgar \& Newell, 2006) as well as standard elements of restorative justice such as group conferencing, repairing harm to the community through service work (Coyle, 2002) and rehabilitation opportunities. This approach would appear to be beneficial as it teaches and reinforces the communication skills necessary to participate in restorative justice, as well as normalising the behaviours required. However, more statistical evidence is needed to fully evaluate restorative justice models and outcomes.

The foregoing all appear positive, but supporters of restorative justice need to be careful of making grand claims that are not supported by evidence, or of ignoring some of the problematic issues raised by restorative approaches, of which a few will now be touched upon.

Of significant concern is the question of whether restorative justice individualises crime too much. Proponents of a shift to a more restorative approach, with its focus on respect and participation, tend to regard it as naturally allying itself with other social justice movements, that there is a similar underlying ethos. However, some critics have contended that as even restorative practices are rooted in the premise that crime is a harm caused by an individual, it fails to address the socio- economic inequalities underlying individual offending (Roche, 2007; Lofton, 2004; Sullivan \& Tift, 2004). Further, resorting to the traditional terminology of "offenders" and "victims" oversimplifies the issue and fails to contextualise the crime and acknowledge that it is statistically likely that at some point the offender will also have been a victim (Sherman \& Strang, 2007; Lofton, 2004). So the important question is to what are people supposedly being restored? If it is the existing arrangements of power and the entrenched inequalities and marginalisation of certain groups whether because of race, class, gender or some other basis, the transformative potential of restorative justice will be hampered. To achieve restorative justice outputs most fully, restorative justice cannot be seen in isolation, but must be underscored by considerations of the relationships between poverty, inequality and offending and the cycles of crime these perpetuate.

Another area of critique challenges one of the basic founding principles of restorative justice, namely that it puts the victim at the centre of the criminal justice system. This is of particular importance here, where the focus is on the offender and the prison setting. Is restorative justice as victim-friendly as it purports to be? Of course it must be noted that even with relatively high profile victims' rights movements, victims do not constitute a homogenous group, all sharing the same responses and needs. Indeed what may seem a petty crime to one person could be a traumatic event for another: everyone deals with events and difficulties differently. Thus any restorative programme cannot be designed as a one-size-fits-all model, but must have the flexibility to adapt to the particular needs and wants within a range of responses (Richards, 2009).

But even bearing this in mind, is too much being expected of victims? Why should it be assumed they want to participate in restorative 
programmes? These are people who probably have busy lives, of which the crime they have been victim of is only one part. This raises the question as to how fair it is to expect victims of crime to invest time and energy in these processes, especially if the offence was a relatively minor one (Richards, 2009). The concerns regarding this can be reduced by any participation in restorative justice being on a voluntary basis. This must be absolutely clear and those who choose to participate must be doing so in an informed, consensual manner with no feeling of obligation placed upon them.

However, that said, in several evaluations of restorative justice interventions, both victims and offenders report feeling more satisfaction with restorative justice as opposed to criminal justice proceedings (Poulson, 2003; Sherman \& Strang, 2007). Beven, Hall, Froyland, Steels, and Goulding (2005) have reported that in victims, this increased satisfaction is due to increased involvement in the process. In meta-analyses of restorative justice programmes, on average, victims report a more positive outcome when they have participated restoratively than when they do not. Further, restorative justice seems to work better when the harm caused has an identifiable, personal victim, who is invited to meet the offender (Sherman \& Strang, 2007).

It could be argued that in offenders, this effect is replicated as they are actively involved in repairing the harm caused by their crimes; however, more research is required in this area. The increase in support that is often received by offenders once enrolled in restorative programmes may also be of import in increasing satisfaction.

However any statements relating to the achievements or limitations of restorative justice must be approached with caution as the lack of conclusive evidence as to how successfully it meets its own stated outcomes persists. This is partly due to methodological problems in assessing various elements of restorative justice, which is a field incorporating many varied processes, outcomes and interventions which can take place at different stages of the criminal justice process, pre or post charge, conviction or sentence.

Perhaps a key question in the use of restorative justice in prisons is whether or not it reduces re-offending behaviour. The research presents a contradictory picture. Hall (2010) suggests that one reason for this could be that as there is no one method of practising restorative justice, results of empirical studies cannot be replicated, thus there is little evidence to support or disprove any claims made. On the other hand Doolin (2007) notes that "as the development of restorative justice is practice-led, it is essential that this rapidly expanding practice be informed by sound theory" (p. 428). This poses the question as to how systematic theory can be developed without rigorous research, but also allows examination of the existing research in a critical light without the ability to replicate studies.

A meta-analysis of existing prison-based studies (Latimer, Dowden, \& Muise, 2005) does show that there is a small reduction in recidivism by those who do participate in restorative justice, and attributes this to feeling supported in continuing a life of nonoffending. Wilson et al. (2002) describe offenders having two common responses: "This is huge" meaning that there was more emotional involvement than they initially expected and "I had no idea there were so many people involved in my life". While part of this support can come from meeting with victims and members of the community, it is important to note that in many cases the studies incorporated into the meta-analysis addressed psychological issues which may have contributed to offending, for example 
providing access to anger management, drug or alcohol rehabilitation, counselling sessions or family mediation. Neglecting these additional factors and just focusing on addressing one specific incident of crime may reduce the efficacy of any restorative justice programme. Indeed these feelings of support and need for additional support are emphasised by former offender Peter Woolf in the short film, The Woolf Within (Crocker, 2008).

However there are areas of the research which seem to be less ambiguous. A finding that can be stated more unequivocally is that restorative justice appears to be more effective in dealing with crimes that can be classified as violent or more serious (Sherman \& Strang, 2007). This is interesting because, as mentioned, restorative justice initiatives in the criminal justice system have tended to be concentrated in the youth justice sector, or on adults who have committed relatively minor crimes. Yet it is the case that restorative approaches appear to be more effective on more severe crimes, not only in relation to victims reporting greater levels of satisfaction over their experiences of the justice system, but also in terms of reducing recidivism rates. Concentrating on juvenile justice or the lower end of adult offences may perhaps be the more politically expedient approach to take, given the tough on crime rhetoric and policies usually advanced, but it does raise doubts as to whether restorative justice is realising its full, innovative potential.

Much of the existing literature on restorative justice has involved youth offenders, relatively minor crimes and, on the whole, male offenders. Shapland (2009; 2004) has shown that adult offenders have differing needs, and that there are different issues which need to be considered in developing a restorative justice project which will meet these needs. Particularly, she notes the stronger tradition of prosecuting adults, and more emphasis placed on punishing adults as opposed to providing education or rehabilitation.

\section{The Bahamian and Wider Caribbean Context}

It is interesting to bear in mind this relationship between the effectiveness of restorative justice and the seriousness of the crime in light of the Her Majesty's Prison Fox Hill inmate profiling study which was conducted by College of The Bahamas faculty in 2010 (Minnis et al., 2011). That study found that those inmates most likely to display willingness to participate restoratively were those serving the longest sentences, which implies those convicted of the most serious, and probably violent, crimes. The percentage of those who expressed interest in engaging with their victim and/or the victims' families and to attempt to restore equity generally increased in line with the number of years being served. The interviewers explained restorative justice to the survey participants as meeting with the victim or victim's family to make things better, say they were sorry and restore peace between themselves and the victim or victim's family. Those who responded as being interested or very interested were taken together as displaying a positive response. The lowest proportion of respondents who indicated an interest in restorative programmes was those inmates serving sentences of less than one year (38\%). This rose to $48 \%, 71 \%$ and $72 \%$ among those serving 1-5 years, 6-10 years and 11-15 years, respectively. There was a reduction in interest in participating restoratively among those serving 15-19 years (56\%) and 20-30 years $(58 \%)$. However the proportion of those serving more than 31 years, life or on death row stood at $86 \%$. This of course can be theorised in many ways, and more qualitative research needs to be conducted to ascertain the authenticity of the inmates' claims and their underlying motivations, but the finding on face value does lend credence to the suggestion that restorative justice is not being 
targeted accurately at those who could most benefit.

Since the College of The Bahamas Fox Hill study was conducted, the prison authorities have launched the Sycamore Tree Project run by Prison Fellowship International which brings together offenders and victims. The first programme ran in 2011 and, having proved successful with positive feedback received from victims and prisoners who participated, a second project was initiated in 2012. Introducing the 2012 Sycamore Tree Project, Elliston Rahming, the then Superintendent of Prisons, stated that he envisaged it "will add to our efforts to ensure that the vast majority of inmates leave better than they came, better in the sense that they have a new view of themselves, a new vision of who they are" (Prison Fellowship International, 2013).

Similarly the Royal Bahamas Police Force committed itself to "encourage and support the implementation of a restorative justice process for The Bahamas" in the Commissioner's Policing Plan, 2010 (p. 17). However no clear actions appear to have been implemented and the Commissioner's plans from 2011, 2012 and 2013 make no reference to restorative justice.

Restorative justice programmes may still be in their infancy in The Bahamas, but they appear to be better established in other Caribbean states, for example in Jamaica and Trinidad and Tobago. Specifically, within the prison setting, Trinidad and Tobago appointed a Task Force on Prison Reform and Transformation in 2001. The following year, the Task Force published its report which advocated the use of restorative justice as the foundation of the prison service (report by Baptiste, 2002 as cited in King \& Bartholomew, 2007). In 2007 Trinidad and Tobago established the Penal Reform and Transformation Unit within the Ministry of National Security (and since 2010 under the Ministry of Justice), the remit of which is to "transform the Criminal Justice System using a Restorative Justice Philosophy and Reintegration Penal Policy", rehabilitate offenders and support justice for victims (http://www.moj.gov.tt/content/penal-reformand-transformation-unit-0). By applying restorative techniques the Trinidad and Tobago Prison Service aims to reform offenders by relying on five strategic priorities: Correct, Protect, Restore, Relate, and Reintegrate (Khan, 2011).

However, as previously mentioned, prisons are not environments that are necessarily open to change, and for there to be any chance of successfully transforming the ethos or methods employed, it is essential for the staff to be engaged and cooperative, individually and within the institution as a whole. Trinidad and Tobago have made attempts to alter the role of prison staff, even changing the job title, and thus the emphasis of the position, from Prison Officers to Correctional Officers. Likewise the prisons are now referred to as correctional facilities (King \& Bartholomew, 2007). However, whether such actions will be any more than superficial changes remains open to question. Despite these stated intentions, obstacles to their implementation are highlighted by one of the individuals whose task it was to administer the changes. In an interview in 2011 as he was approaching retirement, John Rougier, the Commissioner of the Trinidad and Tobago Prison Service, noted that "resistance is being experienced today in the prison service as a whole with respect to the implementation of the restorative justice philosophy" (Williams, 2012 , p. 77). Rougier put this down to a lack of understanding of the concept due to inadequate communication. He also expressed the opinion that staff members failed to see what was in it for them. As staff attitudes are so instrumental to the success of restorative justice within prisons it would be valuable to 
conduct research into this throughout the Caribbean, including the attitudes of staff members at Fox Hill in Nassau.

Jamaica has also undertaken a review of its justice system, establishing the Jamaican Justice System Reform Task Force in 2006 in order to identify how to improve and modernise the Jamaican justice system. It published its Final Report in 2007 making farreaching recommendations on how to make the system "more efficient, accessible, accountable, fair and able to deliver timely results in a cost-effective manner" (p. 1). One of the recommendations was to actively integrate alternative dispute resolution and restorative justice initiatives into the justice system. To achieve this end, the Task Force recommended the Jamaican Government build on the knowledge and experience of the Dispute Resolution Foundation, an organisation that has been offering education and training programmes in restorative justice in Jamaica since 1994.

Further, the Jamaican Ministry of Justice has implemented a National Restorative Justice Programme with the stated objective of finding "a pathway for transformation to a more secure, just, cohesive and peaceful Jamaican society" (2012, p. 42). The goals of the National Programme deal with all aspects of restorative justice at the individual, group and community levels. One of the goals directly addresses the prison setting and the need to "reduce recidivism by addressing the underlying causes of criminal behaviour and supporting the constructive reintegration of the offender into the community" (2012, p. 42).

Arguably then, taking into account the firmly established work of the Dispute Resolution Foundation and the adoption of a comprehensive National Programme which looks to mainstream the restorative approach throughout the system, Jamaica is at the forefront of administering restorative approaches in the Caribbean. However, more empirical research needs to be conducted throughout the region to ascertain how well these policies are being translated into practice, particularly in the prison environment.

\section{CONCLUSION}

More evaluative research projects are required before a definitive judgment can be made on the benefits of restorative justice in prisons, particularly qualitative data as to the reasons offenders choose to participate in restorative justice; the expectations they have regarding restorative justice; and the outcomes offenders achieve through participation in restorative justice. These studies need to bear in mind the scientific research principles outlined earlier by Hall (2010), especially reliability and replication issues, as this will allow for more critical analysis of suitable projects. Further research of prisons using the whole institution restorative approach is also required to compare this with smaller, discrete projects. Despite this, the available literature appears to suggest that restorative justice in prisons is beneficial in terms of reducing recidivism and increasing feelings of satisfaction for both victims and offenders in terms of the justice received.

In setting up a prison based restorative justice project, care needs to be taken to listen to the offenders' aims and the outcomes required (Toews, 2002) and to ensure that the project provides a means of meeting these needs and reaching desired outcomes. Linking with the criminal justice system and other outside agencies, for example victim support, rehabilitation services, or community payback schemes, appears to lead to more positive outcomes and a reduction in recidivism. These links also appear to be the first step in a move towards creating a fully restorative prison service. 
It may be tempting to dismiss the possibility of developing more restorative prisons as idealistic, if not hopelessly naïve. Admittedly it will not be easy, and there are practical difficulties to be addressed in addition to the political and theoretical ones. By their nature and purpose, prisons are difficult places to gain access to; entrenched social and economic interests make it hard to instigate change, as do ingrained attitudes within the regime which can remain obstinately opposed to new methods (Dhamia et al., 2009). What is needed are those who believe there is a better, more humane way of responding to crime and the harm it causes to individuals and communities, to keep pressing the issue. However there are tools that can be relied upon in the argument. International law provides support in that Article 10(3) of the 1966 International Covenant on Civil and Political Rights, to which The Bahamas is a state party, provides "the penitentiary system shall comprise treatment of prisoners the essential aim of which shall be their reformation and social rehabilitation" (p. 171). Restorative justice can better achieve this aim than conventional retributive methods.

\section{REFERENCES}

Achtenberg, M. (2000). Understanding restorative justice practice within the Aboriginal context. Forum on Corrections Research, 12(1), 32-34. Retrieved from http://205.193.117.157/text/pblct/forum/e12 1/121j_e.pdf

Armour, M. P., Sage, J., Rubin, A., \& Windsor, L. C. (2005). Bridges to life: Evaluation of an in-prison restorative justice intervention. Medicine and Law, 24(4), 83151.

Ballor, J. J. (2008). To reform or to abolish: Christian perspectives on punishment, prison and restorative justice. Ave Maria Law Review, 6(2), 481-512.

Bazemore, G., Zaslaw, J. G., \& Riester, D. (2005). Behind the walls and beyond: Restorative justice, instrumental communities and effective residential treatment. Juvenile and Family Court Journal, 56(1), 53-74. doi:10.1111/j.17556988.2005.tb00102.x

Beven, J. P., Hall, G., Froyland, I., Steels, B., \& Goulding, D. (2005). Restoration or renovation: Evaluating restorative justice outcomes. Psychiatry, Psychology and Law, 12(1), 194-206.

doi:10.1375/pplt.2005.12.1.194
Boyes-Watson, C. (2004). What are the implications of the growing state involvement in restorative justice? In $\mathrm{H}$. Zehr \& B. Toews (Eds.), Critical issues in restorative justice (pp. 215-226). Monsey, NY: Criminal Justice Press.

Coyle, A. (2001, May). Restorative justice in the prison setting. Paper presented at the meeting of the International Prison Chaplains Association (Europe), Driebergen, The Netherlands.

Coyle, A. (2002). The restorative prison project: The myth of prison work. Prison Service Journal, 144, 22-29.

Crocker, M. (Producer and Director). (2008). The Woolf within, [Motion picture]. Bristol, England: Level Films. Retrieved from http://www.youtube.com/watch?v=A1s6wK eGLQk

Daly, K. (2002). Restorative justice: The real story. Punishment \& Society, 4(1), 55-79. doi:10.1177/14624740222228464

Dhamia, M.K., Mantle, G., \& Fox, D. (2009). Restorative justice in prisons. Contemporary Justice Review, 12(4), 433-448. doi:10.1080/10282580903343027 
Dignan, J. (2002). Restorative justice and the law: The case for an integrated, systemic approach. In L. Walgrave (Ed.), Restorative justice and the law (pp. 168-190). London, England: Taylor \& Francis.

Doolin, K. (2007). But what does it mean? Seeking definitional clarity in restorative justice. Journal of Criminal Law, 71(5), 427-440. doi:10.1350/jcla.2007.71.5.427

Duff, R.A. (2003). Restoration and retribution. In A. Von Hirsch et al. (Eds.), Restorative justice and criminal justice: Competing or reconcilable paradigms (pp. 43-60). Oxford, England: Oxford University Press.

Edgar, K., \& Newell, T. (2006). Restorative justice in prisons: A guide to making it happen. Winchester, England: Waterside Press.

Findlay, M. (2002). Beware of the dog: Assaults in prison and cultures of secrecy. Current Issues in Criminal Justice, 14(1), 119-120.

Focht-Perlberg, J. A. (2009). Two sides of one coin: Repairing the harm and reducing recidivism: A case for restorative justice in re-entry in Minnesota and beyond. Hamline Journal of Public Law and Policy, 31(1), 219-272.

Gilligan, J., \& Lee, B. (2005). The resolve to stop the violence project: Reducing violence in the community through a jail-based initiative. Journal of Public Health, 27(2), 143-148. doi:10.1093/pubmed/fdi011

Goulding, D., Hall, G., \& Steels, B. (2008). Restorative prisons: Towards radical prison reform. Current Issues in Criminal Justice, 20(2), 231-242.

Gromet, D. M., \& Darley, J. M. (2006). Restoration and retribution: How including retributive components affects the acceptability of restorative justice procedures. Social Justice Research, 19(4), 395-432. doi:10.1007/s11211-006-0023-7

Hall, G. (2010). Clinical relevance of restorative justice. In J. Brown \& E. Campbell (Eds.), The Cambridge handbook of forensic psychology (pp. 354-360). Cambridge, England: Cambridge University Press.

Hurley, M. H. (2009). Restorative practices in institutional settings and at release: Victim wrap-around programs. Federal Probation, 73(1), 16-22.

Jamaica Ministry of Justice. (2012). The national restorative justice policy. Retrieved from http://www.moj.gov.jm/sites/default/ files/rj/Restorative\%20Justice\%20Policy_Re vised_\%20Final_Policy_March_18.pdf

Jamaican Justice System Reform Task Force. (2007). Final report. Retrieved from http://www2.ohchr.org/english/bodies/hrc/d ocs/ngos/JJSR_Jamaica_HRC103.pdf

Jenkins, M. (2004). How do culture, class and gender affect the practice of restorative justice? Pt.1. In H. Zehr, \& B. Toews (Eds.), Critical issues in restorative justice (pp. 311-324). Monsey, NY: Criminal Justice Press.

Katounas, J., \& McElrea, F. (2002). Restorative justice in New Zealand prisons. Prison Service Journal, 140, 16-18.

Khan, F. (2011). Summary of some of the main challenges, measures and best practices relative to Trinidad and Tobago Prison Service. Retrieved from http://www.oas.org/es/cidh/ppl/actividades/s eminario2011/2011TT.pdf

King, K., \& Bartholomew, T. (2007, March). Identifying and predicting the correctional orientation of Trinidad and Tobago's correctional officers: Implications for prison reform. Paper presented at the Eighth Annual SALISE Conference, St. Augustine, 
Trinidad and Tobago. Retrieved from http://sta.uwi.edu/conferences/salises/docum ents/King\%20K.pdf

Latimer, J., Dowden, C., \& Muise, D. (2005). The effectiveness of restorative justice practices: a meta-analysis. Prison Journal, 85(2), 127-144.

doi:10.1177/0032885505276969

Liebmann, M. (2007). Restorative justice: How it works. London, England: Jessica Kingsley.

Lofton, B. P. (2004). Does restorative justice challenge systematic injustices? In H. Zehr $\&$ B. Toews (Eds.), Critical issues in restorative justice (pp. 377-386). Monsey, NY: Criminal Justice Press.

Minnis, J., Symonette, E., Gibson, T., \& Stevenson, M. (2011). A profile study of inmates at H.M.P, Fox Hill, Bahamas. Unpublished manuscript, The College of The Bahamas.

Naser, R., \& Visher, C. (2006). Family members' experiences with incarceration and re-entry. Western Criminology Review, 7(2), 20-31.

Newell, T. (2002). Restorative justice in prisons: The possibility of change. Cambridge, England: Cropwood Fellowship Programme.

O'Brien, P. (2001). "Just like baking a cake": Women describe the necessary ingredients for successful re-entry after incarceration. Families in Society: The Journal of Contemporary Human Services, 82(3), 287295. doi:10.1606/1044-3894.200

O'Doherty, S. (2004). Restorative justice and reintegration. Criminal Law and Justice Weekly, 168(37), 708.

Poulson, B. (2003). A third voice: A review of empirical research on the psychological outcomes of restorative justice. Utah Law Review, 1, 167-204.
Prison Fellowship International. (2013). PF

Bahamas celebrates their second Sycamore Tree Project. Retrieved from http://www.pfi.org/cjr/newsitems/pfbahamas-celebrates-their-second-sycamoretree-projectae/?searchterm=None

Republic of Trinidad and Tobago Task Force on Prison Reform and Transformation. (2002). Final report. Retrieved from http://ttprisons.com/downloads/taskforcerep ort.pdf

Richards, K. (2009). Taking victims seriously? The role of victims' rights movements in the emergence of restorative justice. Current Issues in Criminal Justice, 21(2), 302-320.

Roche, D. (2007). Retributive and restorative justice. In G. Johnstone \& D. W. Van Ness (Eds.), Handbook of restorative justice (pp. 75-91). London, England: Routledge.

Royal Bahamas Police Force. (2010). Commissioner's policing plan 2010: Integrated crime prevention, intervention and response strategy (ICPIRS). Retrieved from http://www.royalbahamaspolice.org/ archives/cop_policyplan_2010/CPP_2010.p df

SACRO National Office. (2006). Young people and restorative justice. [Information leaflet]. Edinburgh, Scotland: Author. Retrieved from http://www.sacro.org.uk/ YoungPeople_RestorativeJustice_leaflet_N AT-403.pdf.

Sawin, J. L. \& Zehr, H. (2007). The ideas of engagement and empowerment. In G. Johnstone. \& D. W. Van Ness (Eds.), Handbook of restorative justice (pp. 41-58). London, England: Routledge.

Saxton, S. (2005). Restorative justice in a Canadian prison. Prison Service Journal, 158, 41-44. 
Shapland, J. (2009). Key elements of restorative justice alongside adult criminal justice. In P. Knepper (Ed.), Urban crime prevention, surveillance, and restorative justice: Effects of social technologies (pp. 123-148). Boca Raton, FL: CRC Press.

Shapland, J., Atkinson, A., Colledge, E., Dignan, J., Howes, M., Johnstone, J., Pennant, R., Robinson, G., \& Sorsby, A. (2004). Implementing restorative justice schemes (Crime Reduction Programme): A report on the first year. London, England: Home Office. Retrieved from http://www.restorativejustice.org.uk/resourc e/ministry_of_justice_evaluation_implement ing_restorative_justice_schemes_crime_red uction_programme_the_first_year_report/

Sherman, L.W., \& Strang, H. (2007). Restorative justice: The evidence. London: The Smith Institute.

Stern, V. (Ed.). (2002). We don't waste prisoners' time and we don't waste bicycles: The impact of restorative work in prisons. London, England: International Centre for Prison Studies, King's College.

Sullivan, D., \& Tifft, L. (2007). What are the implications of restorative justice for society and our lives? In H. Zehr, H. \& B. Toews (Eds.), Critical issues in restorative justice (pp. 387-400). Monsey, NY: Criminal Justice Press.

Toews, B. (2002). Offenders and restorative justice: Listening to prisoners raises issues about prison-based restorative justice. VOMA Connection. St. Paul, MN: Victim Offender Mediation Association.

United Nations. (1966). International covenant on civil and political rights. Retrieved from http://treaties.un.org/doc/ Publications/MTDSG/Volume\%20I/Chapter \%20IV/IV-4.ed.pdf

United Nations Office on Drugs and Crime. (2006). Handbook on restorative justice programmes. New York, NY: United Nations. Retrieved from http://www.unodc.org /pdf/criminal_justice/06-56290_Ebook.pdf.

Walker, L., \& Greening, R. (2010). Huikahi restorative circles: A public health approach for reentry planning. Federal Probation, 74 (1), 43-47.

Wheeldon, J. (2009). Finding common ground: Restorative justice and its theoretical construction(s). Contemporary Justice Review, 12(1), 91-100. doi:10.1080/10282580802681774

Williams, D. (2012). Interview with John Rougier, Commissioner of Prisons of Trinidad and Tobago. In J. K. Singer, D. K. Das, \& E. M. Ahlin, Trends in corrections: Interviews with corrections leaders around the world (pp. 71-99). Boca Raton, FL: CRC Press, Taylor \& Francis Group.

Wilson, R. J., Huculak, B., \& McWhinnie, A. (2002). Restorative justice innovations in Canada. Behavioral Sciences and the Law, 20, 363-380. doi:10.1002/bsl.498

Witvliet, C. V. O., Worthington, E. L., Root, L. M., Sato, A. F., Ludwig, T. E., \& Exline, J. J. (2008). Retributive justice, restorative justice, and forgiveness: An experimental psychophysiology analysis. Journal of Experimental Social Psychology, 44(1), 1025. doi:10.1016/j.jesp.2007.01.009

Zehr, H. (2002). The little book of restorative justice. Intercourse, PA: Good Books. 